water supply, sewage disposal and pollution, methods of collecting and examining specimens, and a long book list for further reading. Throughout the author emphasises conservation aspects. Although this is not an identification manual, the abundance of good plates and line drawings - 16 colour plates, 46 half-tone plates and 88 text figures - will help readers to get to know the names of freshwater organisms.

An excellent introduction to freshwater biology for teachers and students in schools and colleges, the clarity of the text also makes this a very attractive book for the amateur naturalist, conservationist and angler. Its publication coincides with the Save The Village Pond Campaign for which it provides helpful background information on pond ecology. An excellent book with a wide appeal.

URSULA BOWEN

\title{
Conservation in the Soviet Union, by Philip R. Pryde. Cambridge University Press, $£ 5.00$
}

The author, who is Associate Professor of Geography at California State University at San Diego, and specially concerned with environmental problems in the Soviet Union, has compiled a detailed, balanced and lucid account of the policy and practice of conservation and its success and failure in the largest country on earth. The first survey in English - and admirably comprehensive - it embraces, for instance, history, legislation, administration. the extraction and conservation of timber and mineral resources, and environmental pollution. The 27 appendices include a list of endangered mammals and of proposed natural parks, texts of Soviet conservation laws and a table of the composition of Soviet forests. There is a laudably accurate index and a 31-page bibliography.

The author analyses the major problems - for example, enforcing the conservation legislation, stopping the widespread poaching and the bad water pollution - and praises both the conservation education and the work of the zapovedniki, the nature reserves, numbering 68 in 1966 and covering some 10.6 million acres. Specified by law as being 'for scientific research and cultural-educational purposes', almost all zapovedniki have their own research laboratories, scientific staff and museums. Many were created primarily to preserve some unique or threatened species of plant or animal life such as the fur seal and spotted deer.

No major species has apparently become extinct on Soviet territory since the tarpan was exterminated a century ago. And the species greatly depleted earlier this century (e.g. beaver, sable, saiga) have been helped to a strong recovery. One great success story, which the Russians share with the Poles, is that of the European bison, or wisent: only 48 existed in the world in 1927 , but by 1965 a breeding programme.in the USSR had achieved 231 full-blooded wisents and the number is now probably doubling every five years.

JOHN MASSEY STEWART

\section{Wildlife Conservation, by $H$. J. Frith. Angus \& Robertson, $£ 8.00$}

Conservation is planned management of a natural resource and the need for careful but flexible, informed management is a recurrent theme of this timely book. Harry Frith, Chief of the CSIRO Division of Wildlife Research, has done his country a service in presenting this well-documented account with its emphasis on the importance of conserving habitats along with animals.

A concise description of Australia's vertebrate fauna is followed by one of the vegetation, the preferences of various animals for different habitats, the effects of land use and the alteration of habitats by grazing, clearing, mining, burning, water conservation and pollution. The size of Australia and the concentration of human population in a few places fosters what Frith's predecessor, the late Francis 
Ratcliffe, called the Big Country Mystique - that there are vast virgin areas 'outback'. But the traveller finds the virgin lands recede like a mirage, and there is nowhere that Aborigines and the dingo, Europeans and their introduced sheep, cattle, rabbits, cats, foxes, camels or pigs have not colonised. These invaders, and many others inflicted on the native fauna, are given a separate chapter.

The role of the hunter (American usage) in the social and economic scene is also discussed and the author is generally sympathetic, except to the water buffalo 'safari' which he describes as '... not unlike ... shooting an unusually large and extra wary dairy cow with a high velocity rifle in exotic surroundings'.

The commercial use of Australian wildlife, native or introduced, poses many problems. Red and grey kangaroos are recognised not to be competing with stock to the extent usually thought, but seen as a valuable resource capable, with careful control, of supporting a meat and hide industry.

The study of rare or disappearing species is of special interest to the conservationist and may provide basic information on the reason for low density in one case or on inimical factors in the other. Over the last quarter century a great deal has been learnt of the ecology of some species, but Frith emphasises the need for greater integration of State fauna authorities and the provision of more trained wildlife managers if the 40,000 square miles of National Parks and Reserves and the remaining 3,000,000 square miles of Australia are to be adequately conserved. He ends on a note of qualified optimism about the future, provided that a unified, continentwide approach can be developed, to include the monitoring of wild populations, both rare and common, so that planned management may become a reality.

HARRY V. THOMPSON

\section{A Guide to the Suakes of Uganda, by Charles R. S. Pitman. Wheldon \& Wesley, $£ 12$}

Snakes of the American West, by Charles E. Shaw and Sheldon Campbell. Knopf, New York, $\$ 12.50$

This revised edition of Captain Pitman's classic will be welcomed by herpetologists; its scope extends well beyond the borders of Uganda since many of the species described are also found in neighbouring African countries. The major part of the book is devoted to detailed synoptic accounts of the 98 Ugandan species; slightly over half of these are more or less poisonous, though less than a dozen (the cobras, mambas and big vipers) are serious hazards to human life. The descriptions are very thorough, and include notes on sex differences, habits and reproduction, and recorded parasites. There is also an introductory section dealing with zoogeography, classification (with keys to recognition), the treatment of snake-bite and the general characters of snakes. The book is illustrated by diagrams and by many fine drawings in colour, and the author has clearly been at great pains to compile a full and up-todate bibliography.

In his preface the author says that "the "staccato" style adopted throughout achieved enormous reduction in superfluous words'. This style is suitable enough for descriptive detail, but in places it makes rather painful reading and occasionally even leads to scientific ambiguity. However, it hardly diminishes the book's utility as a work of reference and is perhaps a small price to pay in view of the value of this otherwise handsomely produced volume.

The late Charles Shaw, Curator of Reptiles at the San Diego Zoo, and Sheldon Campbell have also produced an excellent contribution to regional herpetology in their account of the 70 or so snake species in the western states, pleasantly written and containing a great deal of interest to the general herpetologist; for example they describe some important recent experiments which demonstrate that snakes, contrary to general belief among zoologists, are able to hear airborne sounds. There are chapters on snake characteristics, on snakes as pets, and the treatment of snake-bite. 